\title{
Story line and story shape in Sir Percyvell of Gales and Chrétien de Troyes's Conte du Graal
}

\author{
Ad Putter
}

\section{Introduction}

The romance of Sir Percyvell of Gales (henceforth Percyvell) was probably composed in the north of England early in the fourteenth century but obviously enjoyed widespread popularity in medieval England. ${ }^{\mathrm{I}}$ Geoffrey Chaucer, who quoted two lines of it in his parody of popular romance Sir Thopas, evidently knew it well, and the anonymous poet of the Laud Troy Book (c. I400) included Percyvell in a catalogue of famous heroes celebrated by 'gestoures ... at mangeres and grete festes'; the other heroes in his list - Bevis, Guy, Tristrem - suggest that the poet was thinking of the English Perceval story rather than Chrétien's Conte $d u$ Graal (c. I I 80), on which it is loosely based. ${ }^{3}$ But while (according to the Laud Troy Book) the romance was once popularised by professional entertainers, it has come down to us only in a single manuscript, Lincoln Cathedral, MS 9I, copied around the middle of the fifteenth century by the Yorkshire gentleman Robert Thornton. ${ }^{4}$ In 2288 lines of extended tail-rhyme, Percyvell tells the following story:

King Arthur's sister Acheflour flees with her only child to the forest after her husband Percyvell, Arthur's favourite knight, has been killed in a tournament by the Red Knight. The child, named Percyvell after his father, is thus brought up in the wilderness, ignorant of his lineage and the world of chivalry. One day Percyvell, dressed as usual in goat's skin, meets in the forest three knights of the Round Table (Gawain, Ywain and Kay). When they explain they are Arthur's knights, Percyvell decides that he also wants to be knighted by Arthur. He hurries home to his mother, who initiates him into the rudiments of courtly behaviour. The 
next morning she gives him a ring, and he leaves for Arthur's court.

On his way he comes across a damsel in a castle, and clumsily puts his mother's advice into practice. After exchanging rings with the maiden, he continues his journey to Arthur's court, making his entry on horseback. His curt order that Arthur should knight him forthwith brings tears to Arthur's eyes, for the king recognises in the young Percyvell the features of his own dead brother-inlaw. The latter's killer, the Red Knight, still terrorises Arthur's court; that very moment he rushes in and steals Arthur's golden cup. Percyvell goes after him to retrieve the cup and kills the Red Knight with a well-aimed throw of his javelin. Unable to get his victim's armour off, Percyvell kindles a fire and is just about to set the corpse alight when Gawain intervenes to help him into the Red Knight's armour. Percyvell rides off on his victim's warhorse. En passant he also dispatches the Red Knight's mother, a witch, whom he skewers on his lance. Further adventures unite Percyvell with his uncle, and lead him to Maidenland, where he liberates the castle of lady Lufamour from the Sultan (Gollotheram) and wins her hand in marriage. Arthur and his knights arrive in time for the wedding and Percyvell is knighted by Arthur, who reveals Percyvell's lineage.

A year later Percyvell remembers his mother and sets out to find her. On the way, he meets again the maiden with whom he exchanged rings. She has been bound to a tree by her jealous lover, who suspects her of infidelity. Percyvell defeats the lover in combat and demands his ring back, but it has been given away to appease a cruel giant. Percyvell seeks out the giant (Gollotheram's brother), kills him, and learns from the porter the strange story of the ring: the giant had taken it to a lone widow in the forest to win her love, but she went mad with grief, believing her son to be dead. Percyvell returns to the forest and restrains his mother, who is restored to health by the porter. Together with his mother, Percyvell rejoins his wife and finally makes a good end by dying on crusade. Amen.

In an excellent discussion of medieval popular literature, Rosemary Woolf justly described this as 'a crude piece of work compared with the French and German analogues'.5 Much the same could be (and has been) said for other Middle English romances based on French originals (King Horn, Sir Tristrem, for example), for comparisons tend 
to show that the French romances are subtler and more sophisticated.

Fortunately, it is not always conscious artistry that attracts us in literature, and the most obvious way of reconciling the often-observed crudeness of Middle English popular romance with the satisfaction it has given to many is that 'crude' - or, less pejoratively, 'simple' - stories have powers of their own. 'Crude', as critics like to call popular romance, ${ }^{6}$ is a culinary metaphor, deriving from Latin crudus 'bloody, raw'. In a narrative, the crudités are a story line with a beginning, middle and end. These may be 'cooked' by authors in various ways: the linear order of events may be scrambled by 'anachronies', 7 it may be distorted by the use of point of view, interrupted by descriptions and digressions, and complicated by means of subplots and interlaced stories. Such devices enable authors to create the impression that the events presented are determined not simply by the logic of actions and sequence, the 'proairetic code', as Roland Barthes called it, ${ }^{8}$ but by various other codes. We ask not 'what happens next?' but 'what does it mean'? Is the author telling us something about the psychology of a 'character' (the semic code); is he developing a 'theme' (the symbolic code); is there a mystery or enigma to be solved (the hermeneutic code); or does he appeal to our sense of verisimilitude (the cultural code)?

What the Middle English romances show is that this process of artistic elaboration that turns 'story' into 'plot' (fabula into siuzhet) $)^{9}$ could be reversed by poets sensitive to the direction and shape of a story. While this reverse process has previously been considered as degeneration, it might be described more precisely as the reconversion of 'plot' to 'story' and the foregrounding of the proairetic code at the expense of all others. How does such jargon help? It emphasises, firstly, that the Middle English romancers adapted material purposefully (and not just haphazardly); and, secondly, it emphasises that the impoverishment of some codes in popular romance is compensated for by the reinforcement of another. For instance, because the proairetic code is end-oriented, its dominance produces little description yet powerful closure, and it is no coincidence that in this respect many English romances (e.g. Amis and Amiloun) are more decisive than the French.

The Percyvell-poet is, as I hope to show, a master of the proairetic code: he is clear about where the story is going, and makes sure that we are clear about it too. The importance of that clarity in a work that was once recited by professional entertainers cannot be overemphasised today, when we know popular romances only from reading them in private. In the fourteenth century, however, Percyvell owed most of its popularity not to being read, but to being told and re-told, possibly 
from memory. ${ }^{10}$ This makes a real difference to the structure of narratives. As Nancy Mason Bradbury has argued, tellers and hearers need 'to perceive the tale's structure in workable segments. The "seamlessness" or "structural tautness" prized in the novel discourages reshaping by denying its readers a foothold, so to speak. ${ }^{\text {"I }}$ By contrast with the modern novelist, the Percyvell-poet has sought rather to multiply the 'footholds' that facilitate retellings and memorisations and so ensure the story's survival.

The aural reception of Percyvell, which the Laud Troy Book describes for us, offers a functional context for my argument that the poet set out, systematically, to expose the 'crude' ingredients of narrative: that is, the story line with its beginning, middle and end. My related claim is that he produced a very satisfying ending. This is no mean achievement: Chrétien de Troyes never finished his Conte du Graal, and even by line 8960 , Chrétien's last, the happy ending is nowhere in sight. Not only has the plot got thicker (especially after Gawain has been launched on a parallel quest), but after a comic start Perceval is overtaken by misfortune: he learns that he has killed his mother and left a king crippled and without a realm. For these 'sins', committed unwittingly, the romance extorts a huge emotional price from the hero, without offering him the chance to redeem himself. Perceval's past mistakes retain their devastating finality in the Conte $d u$ Graal. Providing a happy ending, which means resolving the past in the present, thus involved the Percyvell-poet in a drastic overhaul of Chrétien's design; and when we look at the English poet's free adaptation of Chrétien's Conte we should, like the poet, always have that happy ending in mind.

My discussion of the poet's reshaping of his source is in two sections. The first deals with the Percyvell-poet's 'unscrambling' of Chrétien's plot, and considers how this affects the mood of the story. The second deals with the poet's happy ending and asks what makes it, in all senses of the word, fulfilling.

\section{From siuzhet to fabula}

Middle English romances are unusually emphatic when signalling the basics of the story. Both beginnings and endings are commonly indicated by extra-diegetic discourse (a prayer, an address to the audience) and by a range of other signals - titles, incipits and explicits; display script for opening and closing lines, initials, etc. - which appear far 
more frequently in Middle English romances than in pieces that accompany them in the medieval codex. ${ }^{12}$ Chrétien's Conte du Graal and Percyvell both begin with extra-diegetic discourse - a lengthy prologue in Chrétien and a plea for attention in Percyvell - but the greater clarity of the story line in Percyvell becomes evident if we ask the question: where does the story begin? In Percyvell the natural order of events in the story (story order) and the poet's presentation of these events (text order) cannot readily be distinguished. The story commences with what may well be the hero's biological beginning, namely the wedding of Percyvell the elder and Acheflour (I6-48). We then hear, in chronological order, of the nuptial tournament, in which Percyvell senior defeats the Red Knight, who vows vengeance; of the birth of Percyvell junior and the tournament proclaimed on his birthday; of the father's death at the hands of the Red Knight, and the consequent flight of the widow to the forest.

In the Conte $d u$ Graal, story order and text order pull in different directions. Chrétien opens with a morning in spring, when 'the son of the widowed lady of the Waste Forest' ('li filz a la veve dame / de la Gaste Forest', 74-5) rises early. ${ }^{\mathrm{I} 3}$ The deliberately 'irregular' use of the definite article to introduce unknown characters and places (which normally require the indefinite article) warns us that we have entered the story late; the discourse proceeds as if we had encountered them before and no introductions were needed. On this spring morning, Chrétien continues, the boy (not named Perceval till much later in the narrative) goes hunting and meets a group of Arthur's knights, who remain nameless. Determined to become a knight also, he hurries back to his mother to tell her of this meeting. Horrified, she explains why she has kept him away from the chivalric world. The explanation takes us back in time to the reign of Arthur's predecessor, Uther Pendragon: the boy's elder brothers (whom he never knew he had) were violently killed and his crippled father (whom he never knew either) died of grief. To protect her remaining son, the mother fled with him to the forest. Chrétien has plunged us in medias res, restoring Perceval's past to us in a vivid retrospect. Even then the past returns in the obscure form of an enigma. What, for example, is the meaning of the gruesome mutilation of the elder brother: 'Awesome wonders befell the elder, for crows and rooks pecked out his eyes, and that is how people found him dead'? The significance of this is at once asserted (for these are mervoilles, 475) and withheld. The disruptions of sequence and sense sound the first ominous note of the romance - loud enough to worry anyone but the hero, who has better things to do than listen to his 
mother. And since no elucidation of these mysteries is asked from the mother, none needs to be given by the poet. Enter the hermeneutic code.

The main effect of the Percyvell-poet's alternative prehistory and re-ordering of events is to make the past immediately accessible to us and to the hero, since the line that connects the past with the present is direct and unbroken. Compare for example how differently the deaths of the fathers impinge on the protagonists. In Chrétien the father is said, again in the mother's distancing retrospect, to have been wounded in the leg and crippled by a stranger (which gives him an uncanny similarity to the lame Fisher King in the Grail Castle). What is Perceval to make of this? In Percyvell the father is treacherously killed on the son's birthday by the Red Knight, who thereby revenges a humiliating defeat. And what Percyvell is to make of that is no mystery: he must now in turn avenge his father's death, as prophecies predict: 'The bokes says that he mon / Venge his fader bane' (567-9). In short, the meaning of these events is constituted solely by the proairetic code (defeat $\rightarrow$ murder $\rightarrow$ vengeance).

Even where the Percyvell-poet follows his source closely, he tends to naturalise the sequence and de-activate the hermeneutic code. Consider the events that lead the hero into Arthur's court. In Chrétien the sequence is as follows: on his way to the court, Perceval catches sight of a stranger with handsome red armour, who clutches a golden cup. (Hermeneutic code: who is this knight?) Perceval rides on into Arthur's court, finding the king oblivious to his presence. Only when he turns his horse so close to the king that he sends Arthur's hat flying does he emerge from his reverie. The king's explanation again gives Chrétien an opportunity to relay part of the fabula in an analepsis: Arthur has been vexed by the Red Knight, who, some time before Perceval's arrival, had rushed in to steal his cup, and spilled the wine all over Guinevere, who has now left her husband in a huff. Always impatient with retrospects, Perceval wonders with growing irritation what all this has to do with him, and soon departs to claim the Red Knight's coveted armour. He kills the Red Knight with a javelin and is helped into his armour by Yvonet, who alone has witnessed the scene.

The Percyvell-poet rearranges the sequence to avoid an 'anachrony' and the complication of Chrétien's sub-plot (the Red Knight's taunting of Arthur), which has no immediate connection with the hero and takes place in the protagonist's absence. Thus Percyvell does not pass a Red Knight with a stolen cup on the way to Arthur's court, but the villain conveniently postpones his appearance in the narrative - or 
rather his re-appearance (for he earlier featured as the slayer of Percyvell's father) - in order that Percyvell may be present to witness the outrage for himself. All Percyvell then has to do is to pursue the Red Knight and rid the narrative simultaneously of his father's murderer and Arthur's arch-enemy. A further saving on the cast of characters is effected when the person to help Percyvell into his new armour is not a lowly servant (Yvonet), but Gawain, one of the knights (anonymous in Chrétien) whom Percyvell has already met in the Wild Forest.

All this adds up to a remarkable exercise in narrative economy, though I am not sure that it makes Percyvell a 'closer knit and better narrative' than Chrétien's, as Arthur Brown claims. ${ }^{14}$ For these enhancements of narrative transparency evidently leave Percyvell poorer in other ways - in terms of, for example, the 'cultural code' that governs verisimilitude. It may be uneconomical to field Chrétien's lavish cast of characters, including household names, minor characters, as well as various unnamed folk, but, to be world-like, a fictional world too must be populated, ideally with characters who, as regards their familiarity to us, exhibit the same gradations as do real people: some we know well (like Arthur, Gawain, Kay, etc), some we know barely (the Yvonets of this world), and some are seen only once (like Chrétien's nameless knights in the forest). The same applies to Chrétien's unparsimonious plot, which consists of two initially unrelated story lines: the first concerning a hero who comes to court, and the second, over which Perceval accidentally trips, concerning Arthur's stolen cup. Untidy perhaps, but then so is the world, which contains many life stories totally unrelated to ours; and when these intersect they usually do so in the same unrehearsed manner as that in which Perceval collides with the Red Knight. In terms of the symbolic code, too, Chrétien's choice of Yvonet is significant, since Chrétien portrays a hero who, for as long as he is a 'nobody', can only be known by characters who are themselves 'nobodies': ${ }^{\text {Is }}$ by 'little Yvo' the messenger boy (Yvonet is a diminutive), by the Maiden-Who-Never-Laughs, and by the court fool who welcomes the simpleton as a hero-in-the-making. The function of identifying the messianic hero is predictably demystified in Percyvell and, to save on the character cast, reallocated to Gawain and Arthur, the former helpfully confirming that he has seen this bumpkin earlier in the forest, and the latter recognising in Percyvell the likeness to his father.

Is Percyvell better? I think not. But Brown is surely right to consider it a tidier narrative, for all the changes made to Chrétien's Conte improve the continuity of the fabula. We have already considered in 


\section{I78 Ad Putter}

this light the realignment of story-order and text-order, and the redistribution of narrative functions to just a handful of main characters like Gawain and the Red Knight, who, simply by dint of reappearing and being related to other characters, ${ }^{16}$ become, as it were, the very embodiments of narrative continuity.

There are also other, apparently bizarre, changes in detail that work purposefully to the same end. The naming of Percyvell after his father, unique to this story, is an example of such a change, as is the father's motive for holding a tournament to mark his son's birth:

For he wolde his son were gette

In the same wonne. (I I9-20)

The father has expressed his will, and because his untimely death consecrates that wish as his last, the rest of the narrative effectively unfolds under its influence. The premise of the narrative (and the namesharing between father and son) is thus that Percyvell will find his place in the symbolic order and assume, in the name of the father, the heritage of the past from which his mother had tried to cut him off.

In her effort to thwart the father's last wish, the mother actually provides her son with the means to bring it to fruition. In a small but significant departure from Chrétien, she gives to her son his father's spear, which she pretends to have found in the forest, lest it should give the son a clue to the past:

Of all hir lordes faire gere

Wolde scho noghte with hir bere,

Bot a lyttill scotte-spere ${ }^{17}$

Agayne hir son yode.

And when hir yong son yode,

Scho bade hym walke in the wodde;

Tuke hym the scote-spere gude

And gaffe hym in hande.

'Swete modir,' sayde he,

'What manere of thyng may this bee

That ye nowe hafe taken mee:

What calle yee this wande?'

Than byspakke the lady,

'Son,' scho sayde, 'sekerly,

It es a dart doghty:

In the wodde I it fande.' (I 89-204) 
But despite the mother's attempt to purge the object of any paternal residue, the spear comes to objectify the link between father and son, and nothing could be less of a coincidence than the fact that the young Percyvell should revenge his father's death by throwing this dart at the killer.

Thus form and content in Percyvell join forces to emphasise the continuity of the story line. While it would obviously be misleading to say that such continuity is wholly absent from the Conte $d u$ Graal, Chrétien's fabula plainly does not unravel as perspicuously as Percyvell's, either in terms of presentation (witness the temporal distortions) or content. Specifically, compared with Percyvell's mother, Perceval's has been strikingly more successful in erasing the boy's family history. The hero has no name apart from her appellation 'fair son', and no heirloom materialises the affinity between father and son. All that remains of the past are mysterious traces: a brother with his eyes pecked out, a father wounded in the thigh, and so on.

As Chrétien's Conte unfolds, the hero collects, analeptically, more debris from the past. To give an example: after Perceval has visited the Grail Castle, where (obeying his mentor's orders not to talk too much) he did not ask about the grail, Perceval chances upon a damsel under an oak tree, who is holding the corpse of her decapitated lover. The damsel elicits from Perceval a rehearsal of his adventures at the Grail Castle and a confession that he did not ask who was served by the grail. At this point Perceval mysteriously guesses his own name (Perceval li galois), and is then rebuked by the maiden:

'Your name is changed, good friend.'

'To what?'

'Perceval the wretched. Oh, luckless Perceval! How unfortunate you are to have failed to ask all this! You would have healed the good king who is crippled, and he would have regained the use of his limbs and the rule of his land - and you would have profited greatly. But know this now: many ills will befall you because of the sin against your mother [por le pechié ... de ta mère, 3580-I], for she has died of grief on your account. I know you better than you know me; you don't know who I am, but I was brought up with you at your mother's house for a long time: I'm your cousin and you are mine.'

No sooner has Perceval recovered his name than it is changed by the maiden, who, instead of making sense of the story so far, provides a 
retrospective 'explanation' that flouts any normal understanding of cause and effect: because Perceval has failed to ask the question, a king languishes without a realm (since when can a question produce such results?); and he failed to ask the question because he deserted his mother who died of grief (since when does the one entail the other?). ${ }^{18}$ Missing pieces of fabula are retrospectively filled in: Perceval grew up with his cousin, his mother is dead, the crippled king has been waiting to be delivered by a question, but the fabula has become more, not less, enigmatic in the process. As to the future, all Perceval knows is that he is jinxed by a mysterious agency that was set in motion when he left his mother, and that punishes him for obeying his destiny and the laws of the genre (since the hero must leave for there to be a story): 'Many ills will befall you because of the sin against your mother.'

We are far from the cosy world of Percyvell, where the son is bound, in the name of the father, to take after him. The Conte $d u$ Graal bodies forth a spookier world, where processes of 'normal' signification are sabotaged and the hero's progress is thwarted by the spectre of the mother who, like the father in Percyvell, seems to influence her son's life more profoundly from beyond the grave. The most effective way of protecting the impetus to narrative progression, of ensuring that the son takes his father's place, would therefore be to keep the mother harmlessly alive. And that, of course, is what Percyvell does. ${ }^{19}$

\section{Happy ending}

The unstoppable forward impetus, proleptically anticipated by the prophecy that the son will avenge the father, by the father's name and last wish, the heirloom, and so forth, makes Percyvell superior to the Conte $d u$ Graal at least in terms of the resoluteness of its direction and the clarity with which this direction is signposted to the audience. However, I believe that Percyvell is more strongly coded not only for sequence but also for overall shape. To make good the second part of that claim I want to examine the ending, in which the story folds back on itself by reverting to the beginning.

In bringing that pattern to our attention, Percyvell's overtly segmented structure, particularly its strong sense of an ending, makes a crucial contribution. The fitt divisions, probably lost in scribal transmission, may have helped to signal the approach of the end. Thornton copied only the first of these fitt divisions ('Here es a ffytt of Percyvell of Galles', after line 432), presumably because, in a book intended for 
private or family reading, such aids to oral performance had ceased to be meaningful. ${ }^{20}$ But even in the absence of performance-related instructions, the beginning of the end is so well marked in the narrative that we can make a good guess about where the last fitt (or possibly the penultimate one) would have commenced. After Percyvell has achieved his worldly ambitions (having married Lufamour and become king), the story suddenly loses its forward momentum and halts on a portentous 'Now than':

Now than yong Percevell habade

In those borowes so brade,

For hir sake that he hade

Wedd with a ryng.

Wele weldede he that lande;

Alle bewes to his honde -

The folke that he byfore fonde

Knewe hym for kyng.

Thus he wonnes in that wone

Till that the twelmonthe was gone,

With Lufamour his lemman. (I 760-70)

'Now' and 'then' typically introduce new fitts; ${ }^{21}$ when we get both we know we must be making a fresh start. There are other telling signs. For as Percyvell uncharacteristically sits still, the narrative abruptly shifts gear, skipping over a non-eventful year in a single stanza, having devoted many previous stanzas to a couple of days. The accelerating pace is the narrative equivalent to a 'fast forward' to the ending, and is effective not only because it announces an impending finale but also because it allows poets to foreshorten the middle, and, by doing so, to juxtapose beginnings and endings in a contrastive diptych.

As Karl Kroeber observes, 'discrete narrative segments permit effective repetitions of diverse kinds, because only the distinctness of some "unit" (person, act, place, or even phrase) allows sharp recognition of recurrence'. ${ }^{22}$ Percyvell's obvious segmentation has precisely this virtue of highlighting a pattern of recurrence. Especially noticeable, thanks to the spareness of the poem's time-place coordinates, is the recurrence of a season and a setting. I quote the lines that follow on directly from the passage quoted above:

He thoghte on no thyng

Now on his moder that was - 
How scho levyde with the gres,

With more drynke and lesse,

In welles there thay spryng.

Drynkes of welles ther thay spryng

And gresse etys, withowt lesyng -

Scho liffede with none othir thyng

In the holtes hare.

Till it byfelle appon a day,

Als he in his bedd lay,

Till hymselfe gun he say

(Syghande full sare):

'The laste Yole day that was

Wilde wayes I chese;

My modir all manles

Leved I thare.'

Than righte sone saide he,

'Blythe sall I never be

Or I may my modir see,

And wete how scho fare!'

Now to wete how scho fare

The knyght busked hym yare;

He wolde no lengare duelle thare,

For noghte that myghte bee!

Up he rose in that haulle;

Tuke his lefe at tham alle,

Both at grete and at smalle,

Fro thaym wendis he.

Faire scho prayed hym even than,

Lufamour his lemman,

Till the heghe dayes of Yole were gane,

With hir for to bee -

Bot it served hir of nothyng! (I77I-I 804)

The significant place is the well, with which the poet had associated Percyvell in the notorious opening salvo of his romance:

Lef, lythes to me,

Two wordes or thre,

Off one that was faire and fre 
And felle in his fighte:

His righte name was Percyvell;

He was ffosterde in the felle,

He dranke water of the welle -

And yitt was he wyghte. (I-8)

It is difficult to forget that Chaucer parodied these lines in Sir Thopas 'Hymself drank water of the well, / As did the knyght sire Perceyuell' ${ }^{23}$ - and hence tempting to believe that they are bad, one 'of the more creaky features of this poem'. ${ }^{24}$ But the well is a familiar medieval icon of primitive life, as Chaucer must have known, for in The Former Age he described the Golden Age as follows:

A blisful lyf, a paisible and a swete,

Ledden the peples in the former age ...

They eten mast, hawes, and swich pounage,

And dronken water of the colde welle. $(\mathrm{I}-2,7-8)$

It seems harsh, then, to fault the Percyvell-poet's beginning, which through the topos of the well evokes the world before culture of the hero's 'former age'. To this setting, still inhabited by the mother who has in all senses been left behind, the story now returns us mentally, in advance of the hero's actual return.

The significant time is Christmas day. For by another coincidence ('Till it byfelle appon a day') that is not one, it happens that Percyvell's thoughts return to his mother on the very day he left her. Why now? Because the hero is required to fulfil a pattern of repetitions that the poet must have planned from the very beginning, when he boldly altered Chrétien's springtime setting to Christmas:

Tomorne es forthirmaste Yole day,

And thou says thou will away.... (393-4)

As a result of that change, both the beginning and the ending unfold at the same time, at Christmas, not so much in a 'before' and 'after' but quasi-simultaneously along the parallel tracks of cyclical time.

The poet's emphasis on repetition makes it difficult to read Percyvell's rare moment of retrospection as a sign of change, as at least one critic has done: 'Perceval's second quest shows him to be motivated by a deep and positive love rather than by reckless impetuosity. ${ }^{25}$ It may be more to the point to note the blatant subservience of the semic code 
(constitutive of 'character') to the logic of sequence (the proairetic code), which demands that the ending must retrieve the past by repeating it. ${ }^{26}$ Thus Percyvell must leave Lufamour on exactly the same day (and with the same reckless impetuosity) that he left his mother; Lufamour must try to make him stay, because Percyvell's mother did likewise; and Percyvell must disregard her pleas because he earlier ignored his mother's: 'Till on the morne he wolde away - / For thyng that myghte betyde' (4I9-20). Of course, much has changed: Percyvell has become knight and king and can now recognise the wildness of his former ways, but behind these differences the poet makes visible a reassuring continuity, a sense that the past is not irretrievably lost, as in the Conte du Graal, but even now being fulfilled in the present.

This sense is deepened by the curious adventitiousness of Percyvell's homeward journey, which the poet presents as the haphazard quest of an adventurous knight, even though the trajectory is destined to take us back to the beginning:

Now fro tham gun he ryde;

There wiste no man that tyde

Whedirwarde he wolde ryde,

Ne whedir he wolde lende. (I 808-II)

There is no good reason why Percyvell should should keep his mission secret from everyone, but the poet seems less interested in the postulates of ordinary life than in those of romance, where the knight errant 'carries within himself a mysterious purpose, known to him alone, which he will in fact realise, but in a roundabout way - governed not by the logic of cause and effect but by ... the logic of the adventure' ${ }^{27}$ In keeping with this logic, Percyvell happens by chance upon a distressed maiden, who, needless to say, turns out to be the maiden with whom he exchanged rings a year ago:

Bot forthe thus rydes he ay,

The certen sothe als I yow say,

Till he come at a way

By a wode ende.

Then herde he faste hym by

Als it were a woman cry;

Scho prayed to mylde Mary

Som socoure hir to sende. (I 8 I6-23) 
Percyvell, that is, arrives as if in answer to a prayer. The connectives (thus rydes he ... Till he come ... Then herde he) admit only to a temporal relationship between Percyvell's search and what he finds, but the contingencies are organised into a pattern specified by the spare geography ('By a wodes ende'): we must be back on the threshold of Percyvell's past, at the same point where, on the outward leg of the journey, he had found the maiden in the hall.

In Chrétien's Conte du Graal, Perceval's second encounter with the maiden is preceded by the episode of the Grail Castle, in which he fails to ask the question and then meets his cousin who tells him his mother is dead. This pre-history made it impossible for Chrétien to follow up Percyval's reunion with the maiden with a homecoming. Since his mother is dead, Perceval no longer has a home to go back to; when, in some of the later Perceval Continuations, he does return to the Wild Forest of his youth he poignantly finds not a 'home' but his mother's gravestone. But while Chrétien condemned his hero to a life of endless wandering, in Percyvell the hero's fortunate meeting with the maiden is clearly meant to inaugurate the hero's fated return to the beginning. To this end, the Percyvell-poet again altered the chronology of the Conte du Graal (where Perceval meets the damsel on the second day of his travels, one ordinary day ('un jor', 3827), and meets her again some eight days later) ${ }^{28}$ so as to emphasise the 'coincidence' that Percyvell and the maiden's paths had crossed exactly a year ago, on what in Percyvell was the first day of the hero's travels, Christmas day:

'Now to the I sall say:

Appon my bedd I lay,

Appon the laste Yole day -

Twelve monethes es gone.

Were he knyghte, were he kyng,

He come one his playnge:

With me he chaungede a ryng

The richeste of one.' (I $844-5 \mathrm{I}$ )

Unlike secular time, which is irreversible (Chrétien's 'one day' must inevitably be followed by 'another day'), liturgical time is cyclical and so ideally suited to suggest the circular progression of the story to its beginning. That reversibility of time also makes meaningful the maiden's apparent throwaway line 'Were he knyghte, were he kyng', which, though it is a mistake (a year ago Percyvell was neither knight nor king), predicts precisely what Percyvell was destined to become, 
and so reveals a miraculous conjunction between the remembered past and actual present. The maiden's account of the last Christmas makes this Christmas Day the fulfilment of a promise:

He was bothe kyng and knyght;

Wele he helde that he highte:

He loused the lady so brighte,

Stod bown to the tre. (I872-5; italics mine)

And there are yet other promises, still unfulfilled, that make Percyvell's second encounter with the maiden indispensable to the ending, for Percyvell cannot go back without the ring which the mother (uniquely in this version of the Perceval legend) gave him as a token at the start of his adventures:

His moder gaffe hym a ryng

And bad he solde agayne it bryng:

'Sonne, this sall be oure takynnyng,

For here I sall the byde.' (425-8)

But when, after freeing the lady, Percyvell asks to have his ring back, the poet introduces a complication: the 'takenynng' has been given away to a giant, and so Percyvell must go after it and kill the giant. When the porter of the giant's castle gives back the ring, he tells Percyvell a remarkable story: with this very ring his master had tried to court a lady, but on seeing it she went mad with grief, accusing the giant of killing her son.

From the perspective of verisimilitude (Barthes's cultural code) the significance of this 'recognition token', a standard device in Middle English popular romances, ${ }^{29}$ may seem tenuous, as Mills scornfully remarks: 'Since the hero is almost fully grown, it might seem unnecessary to provide the mother with a token by which he can be identified.' ${ }^{30}$ However, the code that makes sense of recognition tokens in popular romances is not so much the cultural as the proairetic code. They function as emblems of and cues to associated actions (separations) and actions-to-come (reunions), and as such they encode, and provide mnemonic support for, the story's subsequent unravelling. The poet's final twist to the story of the ring - its presentation by a giant to Percyvell's mother, who mistakes it for a sign that her son is dead - is also too quickly dismissed by Mills as 'tortuous', for we need only imagine the flat-footedness of an ending without it (Percyvell and the 
maiden exchange rings and the former returns to his mother) to appreciate why it is needed. Happy endings need unhappiness to put an end to, which is why, as Rosemary Woolf noted, the Middle English popular romances 'seem so often to be potential tragedies, which the poet, by ostentatious contrivance, nevertheless brings to a fortunate issue'. ${ }^{3 \mathrm{I}}$ By such contrivance, the ring produces the potential tragedy that might have been: a son killed by a giant (whom Percyvell indeed gets to fight) and a mother insane with grief.

And just as Middle English romancers understood the necessary implication of tragedy in happy endings, so they appreciated that the eventual recognition promised by 'tokens' (rings, cloaks, cups, and so on) is predicated upon prior misrecognition. The dramatic potential of recognition scenes lies in the oscillation between the loss and the recovery of identity, and, by precipitating the oscillation, the 'recognition tokens' of Middle English romance unleash this potential. Take some examples. Orfeo, disguised as a minstrel, returns home with his 'token', the harp; the faithful steward sees it and collapses because the 'recognition device' confirms his belief that his master is dead. Horn returns with his ring to his wife Rymenhild, who nearly commits suicide when she infers from it that her husband is dead. Amiloun, disfigured by leprosy, turns up on the doorstep of his old friend Amis, but is attacked by the latter, who thinks the leper has killed Amiloun and stolen his cup.

Only when we realise that so-called 'recognition devices' serve in the first place to provoke misrecognition, to bring about the imagined loss that makes the final recognition so jubilant, can we admire how loyally the Percyvell-poet continues the tradition. Like Rymenhild, Orfeo's faithful steward, and Amis, Percyvell's mother sees the recognition token and is convinced that her son is dead:

'At the firste bygynnyng,

He wolde hafe gyffen hir the ryng,

And when scho sawe the tokynyng

Then was scho unsaughte.

Scho gret and cried in her mone;

Sayd, 'Thefe, hase thou my sone slone

And the ryng fro hym tone

That I hym bitaughte?'

Hir clothes ther scho rafe hir fro

And to the wodd gan scho go;

Thus es the lady so wo,

And this is the draghte. 
For siche draghtis als this,

Now es the lady wode, i-wys,

And wilde in the wodde scho es,

Ay sythen that ilke tyde.

'Fayne wolde I take that free,

Bot alsone als scho sees me,

Faste awaye dose scho flee:

Will scho noghte abyde.' (2 I48-67)

The 'tortuous' incident follows logically from what the 'tokenyng' in Middle English romance is meant to do, namely to provide the hero, not with a means 'by which he can be recognised' (Mills), but with one by which the culminating moment of revelation can be deferred in the interest of a gratifying climax. In Aristotle's terminology, the token does not provoke anagnorisis (the climactic recognition) but blocks it, by prompting paralogismos (the plausible but false inference). ${ }^{32}$

It might be objected that the digression of the ring spoils the symmetry between the beginning and the ending, but for this the Percyvell-poet makes ample amends. For, as if prompted by the fate of his mother - 'Now es the lady wode, iwys, / And wilde in the wodde scho es' (2I6I-2) - Percyvell responds by regressing to his own wild ways, when, dressed in a goat's skin, he used to outrun the animals in the forest (34I-2, 722-8), as he must now chase his 'wild' mother. And so he abandons his horse, dresses once more in a 'gayt skynne' (2 I97), and vows to catch the lady, whom he reveals to the porter to be his mother:

'I will assaye full snelle

To make that lady to duelle,

Bot I will noghte ryde;

One my fete will I ga

That faire lady to ta:

Me aughte to bryng hir of wa -

I laye in hir syde.'

He sayse, 'laye in hir syde;

I sall never one horse ryde

Till I have sene hir in tyde:

Spede if I may!

Ne none armoure that may be

Sall come appone me

Till I my modir may see,

Be nyghte or by day.' (2 I69-83) 
Percyvell's recognition of his duty is movingly simple, and so it should be. For the debt that we owe our mothers is indeed basic - 'we lay in their sides' - and Christmas seems the right time to remember this. And because Percyvell's duty is primal, I cannot help feeling that the hero's response to his mother's altered state, to become, as far as he can, the little boy he once was, is utterly convincing, not only because of the perfect narrative symmetry that is thereby created (this really is an ending that was implicit in the beginning), but especially because at this juncture the narrative continuities and their limits (Percyvell cannot in other ways regain his youth) express something simple but true about the continuities and discontinuities of life, about how we are and are not the little ones we were, and about how our mothers are and are not what they were when we left them.

As for the final reunion between Percyvell and his mother that follows, it would be hard to find a passage that better illustrates the undemonstrative beauty of Middle English popular romance. So here it is in full:

His armour he leved therin;

Toke one hym a gayt skynne

And to the wodde gan he wyn,

Among the holtis hare.

A sevenyght long hase he soghte;

His modir ne fyndis he noghte,

Of mete ne drynke he ne roghte,

So full he was of care.

Till the nynte day byfell

That he come to a welle

Ther he was wonte forto duelle,

And drynk take hym thare.

When he had dronken that tyde,

Forthirmare gan he glyde;

Than was he warre, hym besyde,

Of the lady so fre.

Bot when scho sawe hym thare

Scho bygan forto dare

And sone gaffe hym answare,

That brighte was of ble.

Scho bigan to call and cry:

Sayd, 'Siche a sone hade I!' 
His hert lightened in hye,

Blythe forto bee.

Be that he come hir nere,

That scho myght hym here

He said, 'My modir full dere:

Wele byde ye me!'

Be that so nere getis he

That scho myghte nangatis fle;

I say yow full certeynly,

Hir byhoved ther to byde.

Scho stertis appon hym in tene:

Wete ye wele, withowtten wene,

Had hir myghte so mekill bene,

Scho had hym slayne that tyde!

Bot his myghte was the mare,

And up he toke his modir thare:

One his bake he hir bare -

Pure was his pryde! (2196-235)

Could any Old French romance have done this better? Well, it so happens that a comparison is available in the Second Continuation of Chrétien's Conte du Graal, where Perceval's 'homecoming' is handled, very competently, as follows:

He journeyed on till evening, but could find no house where he could take lodging; he slept out in the forest, and had nothing to eat all night and was in great discomfort. His horse grazed on the grass around him, which was heavy with dew, until morning came and the sun began to shine. Then Perceval mounted without delay, and rode on until about nine o'clock [tierce] ... He rode swiftly through the forest, following the paths and tracks which he had come to know so long before, until he came to open ground and saw the house that had been his mother's. ${ }^{33}$

There are perhaps readers who think this passage shows up all the inanities of the corresponding one in Percyvell, and they seem to have an excellent case. A year ago, the mother had promised that she would wait for him at home, but it never occurs to Percyvell to look for his mother there. Instead he wanders aimlessly, as if he were a stranger to the forest where he lived for fifteen years. And could not the Percyvellpoet have avoided hackneyed formulas ('A sevenyght long', 'holtes 
hare') and been as precise about time and setting as the French poet, who acknowledges that Perceval knows the forest well? And to those readers I recommend the Continuations (all 58,00o lines of it).

But since there is only one forest in Percyvell, no lengthy descriptions are required to inform us that, when Percyvell 'to the wodde gan ... wyn, / Among the holtis hare', he has gone back to the forest of his youth:

Fyftene wynter and mare

He duellede in those holtes hare. (229-30)

True, 'holtes hare' is formulaic, but the recurrence of the formula is not pointless, for narratives can communicate a sense of déjà vu by what they do (by repeating) as well as say. The numbers too - fifteen years in the forest, seven nights of searching, the ninth day of deliverance - are wholly conventional, but resonate precisely for that reason. Fifteen is the age when noble youths become knights, ${ }^{34}$ and so the poet need only mention Percyvell's age to tell us that he will soon be off. Seven is the number that represents a long period of trial and tribulation; ${ }^{35}$ while nine, the last number in an incomplete decimal series, signals a turning point (hence Percyvell finds the well on day nine). ${ }^{36}$

And yes, it would make sense for Percyvell to take the shortest route home, but perhaps it is realism of a higher order to consider that the success of human enterprises depends not only on our wit (on knowing the way) but also on the cooperation of forces outside our control that must ultimately reward our endeavours. All this is implied by the concatenation of circumstances that leads Percyvell to his mother, circumstances at once wholly fortuitous - Percyvell does not even know where to look for her - and wholly deserved. For surely it is right that Percyvell should become aware of his mother after he has drunk again from the well that served him as a child: 'His righte name was Percyvell /... / He dranke water of the welle' (5-7). No wonder Chaucer remembered these lines when the romance commemorates them so deliberately. And is not it also right that Percyvell should find the well after nine days of fasting: 'Of mete ne drynke he ne roghte, / So full he was of care'? (Would Percyvell have found the well if he had not fasted?) The romance deflects such 'what ifs' by organising events into a pattern of poetic justice, which generously rescues the hero from the gaping holes in cause and effect, and casts accident and potential failure as destiny and heroic achievement.

And could any poet outside the popular tradition have given us 
the poignant words that mother and son speak to each other in Percyvell? The fugitive mother, whom no one had been able to catch ('Faste awaye dose scho flee', 2I66), stands transfixed when she sees a man looking just like her son when he left her: 'Scho bygan forto dare' (22I3). Used of animals, dare means to 'cower', of humans 'to be overwhelmed', of a madwoman possibly both. Then she shouts 'Siche a sone hade I' and is caught by Percyvell before she knows it. (Again we wonder: would Percyvell have managed to catch her if he had not returned as his former self?) Her five words sum up the story as it might have ended, were it not that Percyvell is alive and that, even in her madness, the mother is not changed so irrevocably that she cannot remember him, and, by remembering him, momentarily remember herself. Hence Percyvell's relief on hearing her desperate cry: 'His hert lightened in hye, / Blythe forto bee'. To him this cry means something special: his old mother is still dormant in the madwoman before him.

As Mills observes in a perceptive editorial note (to line I75), the reversal of roles has at the end of the romance become very marked: mother has become 'wild', while Percyvell has become king; he must look after her, carry her on her back, as she once did him; but underlying such reversals is the reassurance that the past and our former selves are not lost forever; that we can, much as this narrative does, return to the beginning. Appropriately therefore, Percyvell speaks his last words of the romance in homage to the tenacity of the human soul:

\section{He said, 'My modir full dere: \\ Wele byde ye me!'}

The phrasing acknowledges the promise that Percyvell's mother made at the beginning ('here I sall the byde', 428), and which she has clung to by an instinct stronger than her mind. Of course, the acknowledgement is lost on the insane woman; but it is not just for her that it is meant: this is the poet's compliment to those readers who have kept the mother's promise in their hearts, and who have waited with her for this moving moment of fulfilment.

These 'crude' qualities, a sense of direction and a sense of narrative shape, make for good stories and happy endings. In my view, the strengths of this and other popular romances lie in this area, in sequence and in shape, contiguity and pattern, and their mutual tensions and accommodations - in short, in the domain of the proairetic code, which, together with the hermeneutic code, imposes its order on the passing of time. (By contrast, the semic, cultural and symbolic codes 
'establish permutable, reversible connections, outside the constraints of time'.$^{37}$ ) About the kinds of meaning that can be encoded by story lines and the shapes in which they are gathered up, literary criticism has had little to say; but, as my remarks about Percyvell will have suggested, I believe that story lines and patterns do speak to us, and can indeed speak more powerfully than non-temporal forms of narrative configuration about the things bound up with the passing of time: about what does and does not persist through change; about contingencies and the structures, including our identities, that can survive and comprehend them. Regrettably, the condition of narrative that brings it closest to the human condition - the fact that narrative, like life, must be 'lived forwards and understood backwards' (Kierkegaard) - has also interested critics least. Perhaps if our respect for stories pure and simple improves - and there are some encouraging signs that this is happening ${ }^{38}-$ Middle English popular romances will become popular with medievalists again.

\section{Notes}

I I cite the slightly modernised text in Ywain and Gawain, Sir Percyvell of Gales, The Anturs of Arther, ed. Maldwyn Mills (London, I992), but have indented all tail-lines.

2 Laud Troy Book, ed. J. Ernst Wülfing, EETS o.s. I2 I-2 (London, I9023), lines 39-40.

3 I assume that the Percyvell-poet knew Chrétien's version (probably from memory). This position has been ably defended by David C. Fowler, 'Le Conte du Graal and Sir Perceval of Galles', Comparative Literature Studies, I2 (I975), 5-20, and by Keith Busby, 'Sir Perceval of Galles, Le Conte du Graal and La Continuation-Gauvain', Etudes Anglaises, 3 I (1978), I98-202, and 'Chrétien de Troyes English'd', Neophilologus, 7I (I987), 596-6I3. The implausible alternative is that Percyvell goes back to a primitive version of a Perceval-legend that can be reconstructed from the earliest extant versions (Chrétien's Conte du Graal, Wolfram's Parzival (c. I2 Io), and Peredur (thirteenth century)). This case is argued at length by Reginald Griffith, Sir Perceval of Galles: A Study of the Sources of the Legend (Chicago, I9I I), and Arthur Brown, 'The Grail and the English Sir Perceval', Modern Philology, i6 (I9I8-I9), 553-68; I7 (I919-20), 36I-82; I8 (I920-2I), $20 \mathrm{I}-28,66 \mathrm{I}-73 ; 22$ (I924-25), 79-98, I I3-32; some errors of fact, based on their misunderstandings of the text, are corrected in my article 'The text of Sir Perceval of Gales', Medium Aevum, 70 (200I), I9I-203.

4 The Thornton manuscript, one of the most important repositories of Middle English romance, is available in facsimile: Thornton Manuscript 


\section{I94 Ad Putter}

(Lincoln Cathedral MS 91), eds D. S. Brewer and A. E. B. Owen (London, I975). For a codicological study see John J. Thompson, 'The compiler in action: Robert Thornton and the Thornton romances in Lincoln Cathedral MS 9I', in Derek Pearsall (ed.), Manuscripts and Readers in FifteenthCentury England: The Literary Implications of Manuscript Study (Cambridge, I983), pp. II3-24.

5 Rosemary Woolf, 'Later poetry: the popular tradition', in W.F. Bolton (ed.), The Middle Ages, Sphere History of Literature I (London, I970, repr. I986), pp. 267-3 I2 (p. 279).

6 E.g. Dorothy Everett on Percyvell, a 'crude romance': 'A characterisation of the English medieval romances', in her Essays on Middle English Literature, ed. Patricia Kean (Oxford, I955), pp. I-22 (p. I2).

7 The term is taken from Gérard Genette's classic study of time in Narrative Discourse, trans. Jane E. Lewin (Oxford, I980).

8 Roland Barthes, $S / Z$, trans. Richard Miller (Oxford, I996), p. I9.

9 The distinction is usually attributed to Boris Tomashevski, 'Thematics' (I925), in Lee T. Lemon and Marion J. Reis (eds), Russian Formalist Criticism: Four Essays (Lexington, I965), pp. 6I-98.

Io On the memorial transmission of popular romances see especially Murray McGillivray, Memorisation in the Transmission of the Middle English Romances (New York, I990). Some critics doubt the importance of oral transmission; for assessments of the debate see Nancy Mason Bradbury, 'Literacy, orality, and the poetics of Middle English romance', in Mark C. Amiodo and Sarah Gray Miller (eds), Oral Poetics in Middle English Poetry (New York, I994), pp. 36-96; and my 'Historical introduction', in Ad Putter and Jane Gilbert (eds), The Spirit of Medieval English Popular Romance (Harlow, 2000), pp. I-I5.

I I Nancy Mason Bradbury, Writing Aloud: Storytelling in Late Medieval England (Urbana, I998), p. 59.

I2 See Murray Evans, Rereading Middle English Romance: Manuscript Layout, Decoration, and the Rhetoric of Composite Structure (Montreal, I995).

I 3 Citations from the French text are from Le Conte du Graal, ed. F. Lecoy (Paris, I984). Translations from Chrétien's Conte and the later continuations are taken from Perceval: The Story of the Grail, trans. Nigel Bryant (Cambridge, I982).

I 4 Brown, 'The Grail' (n. 3 above), p. 554; my italics.

I 5 Cf. Per Nykrog, Chrétien de Troyes: romancier discutable (Geneva, I996), p. I90.

I6 N. G. H. E. Veldhoen, 'I haffe spedde better pan I wend: some notes on the Middle English Sir Perceval of Galles', Dutch Quarterly Review, I I (I98I), 279-86, usefully observes that the Perceyvell-poet improves the internal consistency of the fabula by making almost everyone in this romance blood relatives. This is true also for the villains (the sultan and the giant are brothers) and for Arthurian characters who are not relatives in any other Arthurian texts. Thus Kay is presented, 'impossibly', as Percyvell's cousin. In medieval romance (cf. Malory's Tale of Sir Gareth) blood ties 
readily do duty for what a realist aesthetic would conceive to be subtler ways of securing unity of action.

I7 The manuscript reading 'Scottes spere' led Reginald Griffith to speculate about the 'Gaelic connections' of Percyvell - Sir Perceval (above, n. 3), p. 22 - but, as suggested by J. Campion and F. Holthausen in their editorial notes to Sir Perceval of Gales (Heidelberg, I9I3), it is obviously a corruption of scotte-spere (cf. Old English scotspera 'dart, javelin'). Surpisingly, no editor has had the sense to emend it.

I 8 As Slavoj Žižek (writing about Wagner's version) shrewdly observes, the operation of a 'blind' causality shows up the weakness of the common interpretation of Perceval's failure as 'immaturity': 'It is here that the insufficiency of the Jungian interpretation which centers on Parsifal's "inner development" becomes manifest; by conceiving Parsifal's ability to ask the required question as the sign of spiritual maturity, this approach fails to take notice of the true enigma, which does not concern Parsifal but the other side, the Grail community: how can this single act of asking a question possess the tremendous healing power of restoring the health of the King and thereby of the entire community held together by the King's body?': Tarrying With the Negative (Durham, NC, I993), p. 276, n. 4I.

I9 Hence the presence of the living mother does not, in my view, make Sir Perceval more 'matriarchal' than Chrétien's Conte, as F. Xavier Baron believes: 'Mother and son in Sir Perceval of Galles', Papers in English Language and Literature, 8 (I972), 3-I4.

20 No further extra-narrative asides are found in the manuscript, nor are subsequent fitt divisions marked by large capitals. As Phillipa Hardman has suggested ('Fitt divisions in Middle English romances', Yearbook of English Studies, 22 (1992), 63-80), an alternative explanation for the fact that a number of Middle English romances preserve only the rubric for the first fitt division would be that, knowing the length of the first instalment, readers could easily estimate subsequent ones. However, in the case of the Findern copy (Cambridge University Library, MS Ff. I.6) of Sir Degrevant, the evidence of a half-copied explicit suggests that rubrics were lost in scribal transmission. On the relationship between fitt divisions and oral performance see Bradbury, Writing Aloud, pp. I I4-23.

2 I See Hardman, 'Fitt divisions', p. 72.

22 Karl Kroeber, Retelling/Rereading: The Fate of Storytelling in Modern Times (New Brunswick, NJ, I992), p. 76.

23 The Riverside Chaucer, ed. Larry D. Benson et al. (Boston, I987), Canterbury Tales, VII. 9I 5-I6.

24 Sir Perceval of Galles and Ywain and Gawain, ed. Mary Flowers Braswell (Kalamazoo, I995), p. 69.

25 Baron, 'Mother and son', p. I2.

26 For a fuller analysis of 'redemptive' endings of this kind see Ad Putter, 'The narrative logic of Emaré, in Putter and Gilbert (eds), The Spirit of Medieval English Popular Romance, pp. I57-80. 


\section{I96 Ad Putter}

27 Piero Boitani, English Medieval Narrative in the 13th and 14th Centuries (Cambridge, I982), p. 54.

28 On the precise chronology, see J. G. Gouttebrooze, 'Sur l'étendue chronologique du premier mouvement du Conte du Graal', Le Moyen Age, 3 I (1976), 5-24.

29 For a discussion of 'tokens' in Middle English romance see Richard Firth Green, A Crisis of Truth: Literature and Law in Ricardian England (Philadelphia, I999), pp. 264-82.

30 Ywain and Gawain, ed. Mills, p. I94, note to line 425.

3 I Woolf, 'Later poetry' (n. 5 above), p. 272.

32 I draw here on Terence Cave's Recognitions: A Study of Poetics (Oxford, I988), pp. 39-43.

33 Perceval, trans. Bryant, pp. I48-9.

34 Thus Amis and Amiloun, Horn, and Chrétien's Cligés, are all knighted aged fifteen. The best gloss on this is a passage from the Roman de Fauvel (lines $303 \mathrm{I}-2$ ), cited in J. A. Burrow, The Ages of Man: A Study in Medieval Writing and Thought (Oxford, I986), p. 26: 'Le sanc veint demander sa rente /D'entour $\mathrm{xv}$ ans.' ('Blood begins to asks its due around the age of fifteen.')

35 Isumbras fasts for 'dayes seven' (225) and is a pilgrim for 'sevenn yer' (508): Sir Isumbras, in Six Middle English Romances, ed. Maldwyn Mills (London, I973).

36 E.g. in Athelston, ed. A. Trounce, EETS 224 (London, I95I), lines 38I, $57 \mathrm{I}-3,78 \mathrm{I}-3$, the bishop is on his ninth palfrey before reaching his destination; the blood-brothers walk across nine hot plough-shares, which the bishop blesses nine times.

37 Barthes, $S / Z$, p. 30.

38 Kroeber, in Retelling/Rereading, argues powerfully that professional critics have privileged 'plot' over 'story'; his book is a timely attempt to redress the balance. 